\title{
Erratum: Ethics in compulsory education - Human dignity, rights and social justice in five contexts
}

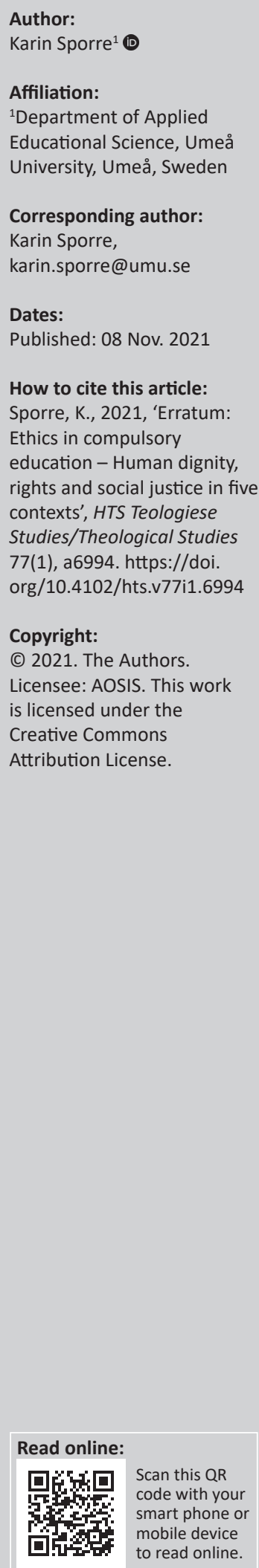

Scan this QR code with your smart phone or mobile device to read online.

In the version of the article initially published, Sporre, K., 2020, 'Ethics in compulsory education Human dignity, rights and social justice in five contexts', HTS Teologiese Studies/Theological Studies 76(1), a5821. https://doi.org/10.4102/hts.v76i1.5821, on page 5, the paragraph detailing the research question was incorrectly written as 'What ethical competence for compulsory schooling do curricula from Namibia, South Africa, California in the USA, Québec in Canada and Sweden prescribe regarding how social justice is expressed through aspects such as class, gender and race, as well as human dignity and human rights?'.

The correct wording is 'The research question of this study is as follows: what ethical competence for compulsory schooling do curricula from Namibia, South Africa, California in the USA, Québec in Canada and Sweden prescribe regarding how social justice is expressed through aspects such as class, gender and race, as well as human dignity and human rights?'.

In addition, in the version of the article initially published, on page 2 and page 7 , a reference is incorrectly cited as 'Sporre et al. in press'. The correct citation for this reference on page 2 and page 7 is 'Sporre et al. 2020'.

These corrections do not alter the study's findings of significance or overall interpretation of the study's results. The publisher apologises for any inconvenience caused. 


\section{Ethics in compulsory education - Human dignity, rights and social justice in five contexts}

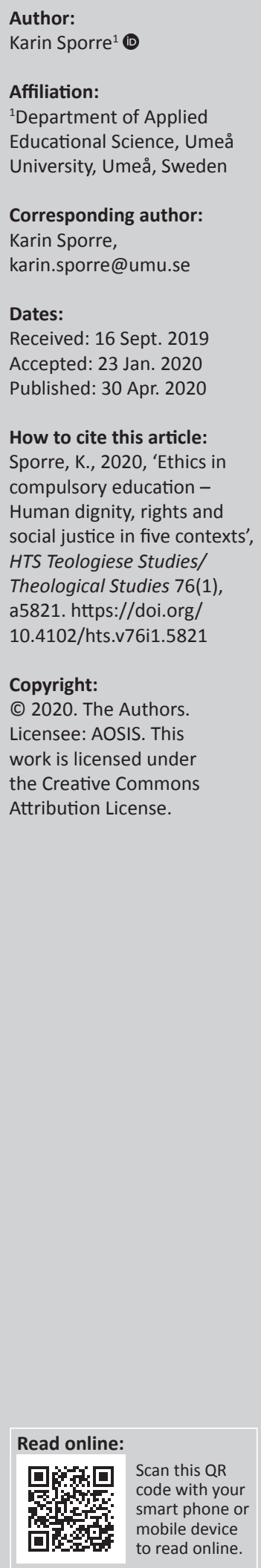

What children learn through their ethics and values education in school is of crucial societal relevance and is directed by school curricula. As curricula vary between countries, an international comparison is of interest. The aim of this study was to compare curricula to reveal variations in how matters of social justice were described in curricular texts, with a special focus on class, gender and race. Curricula from five different contexts were compared: Namibia; South Africa; California State, United states of America; Province of Québec, Canada; and Sweden. This provided the study, originating in Sweden, with crucial comparative material from outside Europe. The studied curricula were systematically searched for the importance and significance of the terms 'poverty/ poor', 'gender', 'equity', 'equality', 'justice', 'race', 'racism', 'human dignity/rights', 'equal value' and Ubuntu. Methodologically, this represented a qualitative content analysis approach with a research interest in intersectionality, that is, in how matters of class, gender and race intersect. The study showed considerable variation between the curricular formulations from the five contexts. For example, texts from California and Québec emphasised equality as a general matter and less as one of intersectionality, compared to Namibia and South Africa as well as Sweden. In general, human rights were emphasised, but human dignity less so. For future curricular development towards education as a global common good, matters of social justice, including sustainability, need critical monitoring. The aspects of intersectionality such as class, gender and race are thus crucial, as is the inclusion of an integrated, participatory view on students' ethical competence.

Keywords: Intersectionality; Social justice; Gender equality; Sustainability; Ethics education; Ethical competence.

\section{Introduction}

Representing an interdisciplinary approach in a study of curricular texts, this study draws on research of various kinds. Crucial empirical and theoretical influences are introduced below.

\section{Ethical and moral views of children and youth: A few empirical examples}

What characterises children's and young people's moral or ethical understandings, and how these are sustained and developed through education, are matters of concern both politically and scientifically. In a Swedish research tradition, over the years, empirical studies on children's life questions and ethical attitudes have explored the morality of children and youth, with considerable concern for the well-being of oneself, family, friends and others, and also care for the environment, being demonstrated (cf. Hartman \& Torstensson-Ed 2007; Manni 2018). Another example, a German quantitative study $(N=2244)$, showed that young people's understandings of human dignity and political rights are linked so that an understanding of the human dignity of others is a strong predictor of the granting of human rights to others (Ziebertz 2016). Another study from the research field represents a reflection over the complexities involved when researching youth and morality in South Africa, given the legacy of apartheid, how it is remembered and how the privileges it offered people still form the conditions of life (Swartz 2011).

\section{Contemporary ethical challenges and education}

Addressing how education might be developed, Van der Walt (2019) discusses how citizenship education could offer a moral compass to South African youth and serve as an expression of a new social contract and a way forward for South African education. On their part, Lynch, Swartz and Isaacs (2017), after having reviewed research articles on anti-racist moral education from 2005 to 2015, concluded by emphasising visibilising (of systemic oppression), recognising (one's own privileges) and strategising (to transform existing inequalities) as means for the development of Note: Special collection entitled UWC, sub-edited by John Klaasen (UWC). 
an anti-racist moral education. In a Swedish context, the challenges of xenophobic nationalism, growing religious plurality and matters related to climate change are mentioned as matters demanding a transformed ethics education (Sporre et al. in press).

Recently, the United Nations Educational, Scientific and Cultural Organization (UNESCO 2015) expressed the need for a rethinking of education, emphasising that matters related to sustainability must now inform education and that education needs to be based on a humanistic vision, recognising anew the dignity and rights of all. The discussion brings the authors to an understanding of education as a common good, a 'collective societal endeavour' (UNESCO 2015:11). Within the discussion of education as a common good, matters of social justice are mentioned, such as gender equality and equal access to education of equal standards (UNESCO 2015). Consequently, the authors argue that approaching education from an ethical point of view today means that matters of social justice, such as diversity, difference and social inclusion or exclusion, must be critically dealt with if education is to be an example of a common good, to be shared amongst and be beneficial to all. Such a normative starting point forms the basis of this study as well, with its focus on compulsory school curricula.

\section{A societal common good and intersectionality}

In political science, from a gender theoretical perspective, matters of access for all and inclusion in relation to a societal common good, given systemic oppression, have been dealt with by Young $(1990,2000)$. In her Justice and the Politics of Difference, Young (1990) coined the concept of the 'five faces of oppression' to denote systemic oppression facing women and minority groups. Crenshaw (1991), in turn, coined the term 'intersectionality' to describe how sex or gender, race and class were complexly interconnected in the structural injustice that African-American women in the United States of America (USA) face. Within theological ethics, Cannon (1988), in her womanist ethics, described how systemic oppressive mechanisms rendered the voices of black American women unheard, amongst black men as well as women, that is, in both political contexts African-American women were left without their own voices being heard. The complexities described by Crenshaw (1991) and Cannon (1988) and emphasised by them and Young (1990) have been further developed within academic work, not least through the use of the concept of intersectionality (cf. Carbado et al. 2013; McCall 2005). The research interest behind this study, with its focus on how class, gender and race come to expression in curricula, draws on this development.

\section{Curricular studies on different levels}

According to the well-known distinctions by Goodlad and Su (1992), empirical educational research can be understood as operating on four levels: the experiential, the instructional, the institutional and the societal levels. The experiential level refers to how children and youth experience the education they are exposed to. On the instructional level, for example, intentions and the actual work of teachers can be studied. On the institutional level, the guidance of education through prescriptive texts is under study. Finally, when the societal level is in focus, education is understood in its wider (national) societal framework. Contemporary curricular studies take an interest in how curricular trends are 'travelling' internationally, against the background of the global neoliberal market economy system and the more specific effects this has on national educational systems, exemplified through the work of Stephen J. Ball (cf. Ball 2009). One aspect of this is how this affects the work and mentality or morality of teachers (Ball 2003; Ball \& Olmedo 2013), but studied are also the effects on classroom practices and how children are affected by the present performance culture with its focus on measurement (Silfver, Sjöberg \& Bagger 2016).

This study, in the terminology of Goodlad and Su (1992), is an example of a study on the institutional and, to some extent, the societal level, as it examines curricula and not, for example, classroom or teacher practices. In addition, it is not an example of a study focusing on travelling policies in the neoliberal market economy. Rather, here the research interest is on how matters of class, gender and race are treated in the studied texts, compulsory school curricula within the five chosen contexts of Namibia; South Africa; California, USA; Québec, Canada; and Sweden. The study is a policy study in which certain political influence on curricula can be traced, but its focus is primarily on the curricular texts.

\section{Ethics education in various studies}

In a recent research review of the field of ethics and moral education including 1940 peer-reviewed articles, the articles were screened regarding the understanding of 'ethical competence' that emerged (Osbeck et al. 2018). The concept of 'ethical competence' was sparsely used as a term, but the dimensions of ethical competence that were identified as a result of the research review are in line with an earlier study in the field, namely, the four categories identified by Rest (1986): moral sensitivity, moral judgement, moral motivation and moral implementation. The work of Osbeck et al. (2018) confirmed Rest's (1986) categories and expanded them, as well as added other dimensions of ethical competence that were not covered by Rest's framework. Another result, so far unpublished, of the research review is that comparative studies of curricula for schooling regarding ethical competence, or more generally regarding ethics education, are rare.

One exception to this is a study by Korim and Hanesová (2010), in which curricular contexts of ethics education in Europe were screened to reveal which subjects ethics education connects to, or whether it is free-standing from other school subjects. However, their study, while still an ambitious curricular overview, does not offer much detail 
as to what the actual content of the ethics education is in the studied countries. Another study by Rothgangel, Skeie and Jäggle (2014) compares European curricula and goes into more detail regarding the content, with a focus on religion in education, and also provides some observations on alternative subjects or learning areas, such as ethics and philosophy.

This present study has a parallel study, focusing on the same five contexts as here and in line with the study by Korim and Hanesová (2010) examining how ethics or values education relates to other school subjects, that is, their curricular contexts (Sporre forthcoming). The present study is an analysis of the same curricular texts, but with a different focus. Both studies use 'ethical competence' as a heuristic tool. Regarding ethics education in curricula from the five Nordic countries, other curricular comparisons have been undertaken (Lilja et al. 2017; Franck forthcoming).

\section{Aim of the study}

Given the background discussed in the previous sections, the focus of this study is on school curricula in five different contexts and how they describe ethical competence regarding class, gender and race, backed by an interest in social justice, a presupposition for education understood as a global common good. The aim of the study is to provide knowledge regarding how compulsory school curricula in Namibia, South Africa, California State in the United States of America, the Province of Québec in Canada, and Sweden vary in their descriptions of how aspects of social justice such as class, gender and race are to be studied in ethics and values education. The variations that emerge can contribute towards a critical development of curricula.

Furthermore, as part of the interest in social justice and the choice of Namibia and South Africa as two contexts in this study, the study has a second aim to provide knowledge about how matters of human dignity and human rights are described in the studied curricula. This second aim is formulated against the background that, as dignity and rights were withheld from citizens during the years of apartheid in Namibia and South Africa, it is of interest to observe whether formulations leaving behind the history of apartheid are possible to trace in the curricular comparison.

As indicated, the study uses qualitative content analysis with a focus on meanings and contexts in the study of the chosen texts (cf. Vaismoradi, Turunen \& Bondas 2013). The use of ethical competence as a heuristic tool, other methodological matters and the specific research question of the study are presented next.

\section{Research design and methodological considerations}

The first study of the comparison of the curricula (Sporre forthcoming) from the five contexts also studied here has the same methodological approach as the present one, but, as indicated, with a different focus. Of interest in that study is a broad overall characterisation of the ethics or values education that the five curricula demonstrate. The electronically available curricula, adopted between 2005 and 2011 and in use in 2015 when the study began, ${ }^{1}$ have in that study been analysed for the use of the three search terms 'ethic*', 'moral' and 'value', with the texts screened and the terms used in that order. Based on the findings, the character of the ethics education is described as tending towards an ethics education for Namibia, the Province of Québec and Sweden, while in the cases of South Africa and California the search generated a result pointing to more of a values education in which constitutional values are emphasised (Sporre forthcoming). The reason for this conclusion is that the search terms 'ethic*' and 'moral' did not generate much concrete results in the curricula for compulsory school, but rather a value emphasis is stronger. The importance of constitutional values is given crucial importance in both cases, slightly more in the South African case than in the Californian one, and also with a more communal than individual rights approach. In other respects, there are also differences between the five curricula, for example, as to how the ethics or values education is named, where it has its curricular place, how extensive it is, how detailed the syllabi are, and finally, whether or not a relationship with a religion education subject exists (Sporre forthcoming).

In this study, the same material (the five curricula) has been analysed using other search terms: 'poverty/ poor', 'gender', 'equity', 'equality', 'justice', 'race', 'racism', 'human dignity', 'human rights', 'equal value' and Ubuntu. This is done in order to follow the focus on class, gender and race and to direct the analysis towards intersectionality. However, initial efforts to use 'class' as a search term were abandoned as it became immediately obvious that in a school context 'class' is the organisational term for the units to which children belong and is used in this sense. Instead, 'poverty' and 'poor' are used. Ubuntu was tentatively added as this concept seemed to carry important content in the Namibian context and perhaps also in South African case, but with the expectation that it would presumably not be used in the contexts of California, Québec or Sweden. As indicated, the choice of the search terms grew out of the research interest in observing how social inequalities are handled in the studied curricula, which could indicate how matters of social justice are looked upon. The connecting of social inequalities to matters of human dignity and human rights was also deemed important as matters of human dignity and human rights can be seen as another side of the coin of social inequalities. Human dignity and rights can be seen as crucial to regain for people having lived or living under oppression as articulated, for example, in texts by Asian women, womanist and feminist theologians (cf. Sporre 2015:28-37, 1999).

The choice of the five contexts deserves some explanation. As the study originates in a Swedish research context, the 1.In 2015, the Californian and Namibian curricula were under revision, but the curricula then in use are the ones that were studied. 
Swedish curriculum was an obvious choice. Comparing Sweden with countries outside Europe could provide interesting material for reflection and curricular development, not least as some comparative research in a European context exists (cf. Korim \& Hanesová 2010; Rothgangel et al. 2014).

The researcher's familiarity with South Africa and, to some extent, Namibia opened up for the possibility to include these contexts. Combining these two countries with a state in the USA and a province in Canada gave a set-up of these two countries that have recently left apartheid with two 'older' democracies, plus Sweden, one of the Nordic welfare states, which is also an older democracy. ${ }^{2}$

In the cases of Namibia, South Africa and Sweden, the curricula are national, while in the USA and Canada, national curricula do not exist; thus, a state and a province ended up being adequate choices. Research colleagues familiar with these contexts suggested the two alternatives as ones that could be of interest. As the intention was to provide variation but still keep the material from becoming too extensive, it seemed reasonable not to include more than five contexts. This offered the opportunity to go into detail regarding the content.

Furthermore, the study was delimited to curricular texts for compulsory school not only to focus on basic education, but also to avoid an overload of material. In Sweden, school is compulsory for 9 years, which is also the case in South Africa. In Namibia, 7 years in school are compulsory. In the USA and Canada, this varies between states and provinces. To achieve comparable material, it was primarily grades 1-9 that were compared, but when a year in preschool used the same curriculum as primary school, that preschool year was included. The next delimitation of studied curricular texts was to identify the school subjects in which ethics education or its equivalent is present. In the Swedish case, the syllabus for the school subject Religionskunskap [Knowledge of Religion] has been studied. It includes ethics as one specific theme within the syllabus. The Namibian syllabi that are studied are from the subject Religious and Moral Education (RME). In the South African case, syllabi for Life Skills and Life Orientation have been studied. In the Californian case, ethics education is found in the so-called History-Social Science Framework (H-SSF). Finally, in the case of Québec, ethics education takes place within the ethics and religious culture (ERC) programme. Of the five cases, this programme has the most extensively developed curricular programme of ethics education. The studied syllabi, adopted between 2005 and 2011 and in use when the study started in 2015, are listed below, after the References section. The choices made mean that curricula and syllabi were studied with ethics or values

2.Using 'democracy' as a signifier raises crucial questions and opens for a number of critical contemporary problems, for example, regarding the representation and influence of minorities, the use of media by political loaters and, in influence of minorities, the use of media by political leaders and, in general, the active involvement of citizens in politics. Here, the term is used to point to the shift in Namibia and South Africa leaving apartheid behind and the opening of the votin systems to all, irrespective of race or skin colour, in 1990 and 1994, respectively. However, the problems of equal rights and access to the political arena remain issues to be dealt with in all five contexts, regardless of their democracy being 'younger' or 'older'. education as the curricular focus. However, matters of social justice can be relevant and appear in a number of school subjects, but the focus here is how they are treated within ethics education or its equivalent.

Discussing analysis in qualitative research, Vaismoradi et al. (2013) distinguish between thematic and content analysis, explaining some differences between the two. One distinguishing aspect is whether an analysis is inductive or deductive. According to Vaismoradi et al. (2013), thematic analysis is more inductive and tries to identify themes hidden within the collected data, often being interviews or enquiries with persons, while content analysis is more deductive and rather deals with openly available aspects of texts. Given their classification, what is at stake here could be called content analysis, as theoretical discussion around intersectionality has directed the research interest and the choice of search terms, thus primarily reflecting a deductive approach. However, the choice of search terms in this study is both deductive and inductive, as the inclusion of Ubuntu amongst the search terms indicates. In addition to this search term being included, the interpretive part of the analytical process - that is, the use of the search terms in relation to the studied texts - can also be said to be inductive. It represents a close study, a careful reading and re-reading of the studied texts, throughout an interpretive process, in which it has been crucial to study the search terms in their specific contexts, focusing, for example, on the meaning of the wider contexts. The analysis of the texts in this study came as the second one in a research process, where I had familiarised myself with the texts through a first study (Sporre forthcoming). Therefore, my knowledge and interpretation of the general context of the text had a bearing on this second interpretation.

As a more general methodological comment, it can be noted that comparing curricula from five different contexts and focusing on their content raise a number of issues, initially that of getting to know the respective contexts well, but later also how to structure the comparison, and finally, how to report on the study to make the results communicable. As mentioned, in this study as in the other one (Sporre forthcoming), I use the term 'ethical competence' ${ }^{3}$ as a heuristic tool when summarising the positions the curricular texts express when searched using the chosen search terms. This means that ethical competence as a concept 'becomes filled' with the respective content from the curricula based on the research focus. In reporting on the specific ethical competence for each case, the most frequent and significant use of the relevant search term(s) in the specific case will be described, meaning that frequency and significance are crucial aspects directing the interpretation. When stating this, the importance of 'significance' must be emphasised. The analysis, although respecting frequency, is much more complex than simply a count of words. The use of search terms and the interpretation of their meaning in the contexts of the texts make the content analysis a qualitative content 3.In Sporre (forthcoming), the discussion on 'ethical competence' and the use of the concept as a heuristic tool is elaborated in detail. 
analysis. Finally, the results of the comparison will initially be introduced in summary, then developed and, finally, critically discussed.

What ethical competence for compulsory schooling do curricula from Namibia, South Africa, California in the USA, Québec in Canada and Sweden prescribe regarding how social justice is expressed through aspects such as class, gender and race, as well as human dignity and human rights?

\section{Ethical competence and dignity in five contexts}

\section{Namibia}

A search through the syllabi of RME from grades R up to 9 for Namibia using the search terms 'poverty/ poor', 'gender', 'equity', 'equality', 'justice', 'race', 'racism', 'human dignity', 'equal value' and Ubuntu clearly demonstrated strong curricular ambitions in favour of gender equity, and an articulation of justice as a crucial value. The notion of human dignity was not used, but the idea of respect for all human beings was introduced via the concept of Ubuntu, taken from African tradition and religions, denoting good relationships between human beings and nature. So, ethical competence can be understood as promoting gender justice and respect for other human beings and nature.

\section{South Africa}

The use of the same search terms, as in the Namibian case, in the study of the South African syllabi of Life Skills (grades R-6) and Life Orientation (grades 7-9) revealed a clear desire to leave behind the divisions of apartheid and build a society based on democratic values, social justice and human rights. Gender was mentioned as one of the background aspects amongst others, such as socio-economic background, race, physical ability or intellectual ability - aspects that are not to matter in the provision of good opportunities for education. The notion of human dignity was not used, but dignity was mentioned once, in this case connected to religions: students in Grade 6 are to learn what is said about dignity in a variety of religions in South Africa. In Grade 7, human rights, as stated in the Constitution of South Africa, assume a crucial role. In summary, ethical competence is to include equal treatment and respect for the rights of all, leaving behind the divisions of the past.

\section{California}

When the Californian H-SSF was analysed for the search terms and what characterises the ethical literacy it prescribes, different search terms emerged as being of importance as compared to Namibia and South Africa. The crucial values relating to ethical competence are equality and justice: equality between all human beings, and justice in front of the state, the nation. Gender equality emerges as something important, contemporarily related to women, and to be studied mainly in a historic perspective, within the provided historic framework of H-SSF. Race and racism are also to be approached historically - also revealing the overall historic construction of the H-SSF. Within a cultural literacy, students need to develop respect for the human dignity of all people, and an understanding of different cultures and ways of life is highlighted. So, ethical competence emphasises justice, individual rights, the equality of all and respect for the human dignity of all people.

\section{Québec}

In the ERC programme of the Province of Québec, the search terms point to a focus on justice as an ethical theme, to be explored in more detail towards the latter stages of compulsory school. Equal value and equality are mentioned as crucial, along with a mention of respect for others. Human dignity is connected to social life in society and as something the programme in general should make students aware of. However, gender equality, or race equality or racism, is not mentioned. Ethical competence is thus emphasised to mean a recognition in a general sense of matters of justice and human dignity, ascribed to all.

\section{Sweden}

The Swedish syllabus for Knowledge of Religion(s) emphasises equality, especially gender equality, in the syllabus for the ethics subtheme. Underlined for the early school years are basic human rights, including children's rights, as an expression of the equality of all people. When the foundational values and the equal value of all human beings are stated and a non-discriminatory agenda is mentioned in the preamble to the overall curriculum, race and racism are not mentioned, whereas 'gender, ethnic affiliation, religion or other belief systems, transgender identity or its expressions, sexual orientation, age or functional impairment' are mentioned (Lgr 2011). Because of the emphasis put, ethical competence must be said to include awareness of matters related to gender equality and the importance of basic human rights.

\section{The five contexts summarised}

In Namibia, ethical competence includes gender justice and respect for other human beings and nature. The idea of respect for all human beings is introduced via the concept of Ubuntu, taken from African tradition and religions, denoting good relationships between human beings and nature. In South Africa, ethical competence includes equal treatment and respect for the rights of others. The divisions of the past and background aspects like gender, socioeconomic background, race, physical ability or intellectual ability are not to matter in learning. Because of the construction of the H-SSF curriculum, in the Californian curriculum, the ethical literacy that is to be developed has to approach ethical themes mainly through historic studies, while a contemporary intersectional understanding of gender, race and class seems difficult to develop. Rather, a 
more liberal understanding of individual citizen rights in front of the state, the nation, comes to the fore. The ERC programme of the Province of Québec, given our search terms, emphasises justice as the crucial ethical theme and human dignity as anchored in religions, and as something students are to be made aware of, but no aspects of intersectionality appear. The Swedish curriculum for Knowledge of Religion(s) emphasises equality, not least gender equality, as well as basic human rights but not human dignity. Race and racism are not mentioned in otherwise quite extensive descriptions of background aspects that should not lead to discrimination.

\section{Reflection}

There may seem to be a great deal of similarities between the five cases regarding the studied matters; however, when the expressions are studied in their contexts, in the actual texts, the differences become obvious. For instance, the ways the Namibian, South African and Swedish curricula frame the matters have a considerably more gender-equality and intersectionality approach to matters of equality and justice, as compared to curricula from California and Québec. The curricula from these two latter contexts reflect perspectives whereby equality and citizen rights are generally understood, as if all individuals are on equal standing and discrimination or oppression need not be problematised as part of an ethical competence to be learnt.

Human dignity is not used much at all as a concept in any of the curricula. My expectation was to find it emphasised in South African and Namibian curricula as something important, explicitly mentioned to strive for, but it was not. However, in the ERC programme, human dignity is actively used as one goal to make students aware of in relation to social life, but in this case as something equally shared among all human beings and not something certain individuals having been exposed to discrimination or oppression need to regain. Interesting to note from the contexts in which human dignity is mentioned to some extent (Québec, California and South Africa) is that human dignity is connected to religions, suggesting that studies of religions can contribute an understanding of what human dignity means.

\section{Ethical competence for compulsory school - Education as a common good}

So where do this comparison and the different curricular approaches take us? What is to be learnt in ethics? What ethical competence is to be developed? The UNESCO report from 2015 underlines the need to rethink education, specified with the direction 'towards a common good?'. In doing this, the authors of the report distance an understanding of the common good in education from the conceptual framework of education as a public good (UNESCO 2015:77-84). By rather arguing for the use of the concept of education as 'a common good', the authors want to move the discussion beyond an emphasis on (economically) measurable aspects of education in which individual success is central, towards an understanding of education as a humanistic, collective endeavour. What should instead matter is that 'the goodness of the life that humans hold in common' becomes the central focus (UNESCO 2015:78). The report also underlines the need for an understanding and acceptance of a plurality of perspectives and worldviews in policy formation when it is related to knowledge production, as well as participatory democratic processes in the development of knowledge (UNESCO 2015:77-79).

When aspects of social justice and their expression in curricula as examples of ethical competence have been explored in this study, variations in emphasis have emerged. This refers to variations such as which aspects of concrete justice issues - like gender equality, racial justice, fairness vis-à-vis the needs of less able persons, discrimination because of age, etc. - have been demonstrated. Justice and equality for all, in more general terms, have also been found, but also as variations in how to approach human dignity and human rights. Given all this, how can an adequately contemporary ethical competence be described in curricular contexts?

\section{Race, racism and racialisation}

Starting this discussion of variations and future directions regarding social justice in matters of race and racism, the South African curriculum is the one context in which such matters are addressed through an explicit naming of them, emphasising the need to leave behind discrimination based on race. The results of the research review by Lynch et al. (2017) pointed to, amongst others, the need for visibilising (of systemic oppression), recognising (own privileges) and strategising (to transform existing inequalities) as means for the development of an anti-racist moral education. In their study, they found that research regarding anti-racist moral education had almost exclusively dealt with tertiary education and, only to a limited extent, secondary education, thus barely with compulsory school; thus, its relevance could be problematised in relation to this study. Having noted this, it is still interesting here to compare the explicit mention of racism in the South African curriculum to the complete silence of the ERC programme and the Namibian and Swedish curricula, as this exemplifies tendencies of a lack of mention as a way of not visibilising systemic oppression. Of special interest is the Swedish silence, as many other grounds of discrimination are explicitly mentioned in the curriculum; how can this specific silence be interpreted? When sociologists Mulinari and Neergaard (2017) discussed the 'Swedish racial regime' against the background of Critical Race Theory, they pointed to how matters of race and racism are silenced and neglected in various ways, both in academic research and through a state 'neutrality' concealing both colonialism 
and racism. As part of a possible remedy, they pointed to intersectionality and its capacity to open for analysis of how power patterns intersect and how to theorise concealed racialisation and colonialism in a Swedish context. Applied to a discussion of curricula, an explicit mention of racism as one ground for discrimination, amongst others, should then be in line with the suggestions by Lynch et al. (2017) as a way to visibilise systemic oppression. In a Swedish, or other European, context, it could additionally assist in counteracting nationalist tendencies with Nazi influence, that is, political tendencies that are currently on the rise (cf. Sporre et al. in press).

\section{Class, socio-economic background and economic behaviour}

Moving next to class as an issue in the curricula, the clearest mention of these matters appears in the South African formulation that learners should, irrespective of socioeconomic background, be equipped with knowledge, skills and values to, on equal footing, become citizens in a free South Africa. In the other contexts, related matters can be said to be indirectly present through formulations of equality, generally, and equal access to education; however, in analogy with the reasoning above around the Swedish curriculum, such 'non-explicit mention' may mean a concealing of matters, that is, those of economic inequality or class. However, in the Namibian case, with its welldeveloped and detailed syllabus for RME, in Grade 6 as part of a theme on African traditions and the human community, also called Ubuntu, children are to develop their competence in relating the economic activity of different societal groups to the values, lifestyles and ideas of these groups. This exemplifies an approach which, critically used, can open up for an analysis of differences in lifestyles, economic behaviour and resources.

\section{Gender, gender equality and black feminism}

Gender and gender equality comprise the aspect of social justice that is most often explicitly mentioned when comparing the three studied aspects of race, class and gender. It appears most clearly in the Swedish curriculum, followed by the Namibian, South African and Californian curricula. In the ERC, there is no mention of gender. If the way in which aspects of power are negotiated vis-à-vis one another from an intersectionality perspective is studied, it is obvious that the Swedish emphasis on gender equality is not negotiated in relation to class or race. To connect again to the discussion of Mulinari and Neergaard (2017); they also stress the importance of bringing perspectives from black feminism into a Swedish context to make visible how complexly matters of class, race and gender intersect, and how racialisation is gendered. Given the onedimensional focus on gender equality in the Swedish curriculum, such a point seems relevant. It is of value to consider also in the other contexts when to address issues of gender equality.

\section{Human dignity, generally or as resistance?}

Moving next to matters of human dignity and human rights, starting with human dignity, it is mentioned as an overarching goal in the ERC programme to be recognised and related to showing respect for others. In this programme, as well as in the Californian and South African ones, human dignity is connected to religions and is said to find an expression within them. In Sporre (2015), based on a study of several feminist texts including texts by a black womanist, I argue for an understanding of human dignity that emphasises the need to have one's human dignity restored as a crucial way of resisting oppression, and to have one's identity restored in relation to having experienced oppression. Of importance to note in this particular study is that, as religions are indeed contexts that can be complicit in the oppression of women, a reference to religions for understanding human dignity needs to be critically questioned.

In the Namibian curriculum, 'human dignity' is not used as a term, but the RME curricula show an interesting ethos. The Namibian curriculum has a focus on the student as a person coming to school already with a worldview, with a self to be understood and respected, not only by students themselves but also by teachers and schoolmates, indicating an interpretation of human dignity expressed in other words, as part of an Ubuntu worldview.

\section{Human rights: A joint moral discourse?}

Coming next to human rights, this is the search term for which the least differences are noticeable as all curricula mention it, even though the ways in which this is done vary. In both Namibia and Sweden, human rights comprise a crucial theme for the early years of school, up to Grade 3, but are also to be dealt with further on. The South African curricula for grades 7 and 8 prescribe a study of human rights in the light of the new constitution. The H-SSF curriculum gives importance to human rights as an important part of an ethical literacy, but does not offer much information regarding how to undertake the study. The ERC programme, briefly addressing matters of human rights, repeatedly refers to Canada's and Québec's rights charters. Although the approaches vary, it seems obvious that human rights in the five contexts have a status of recognised moral conventions in line with UNESCO (2015) or the moral philosophical discussion by Benhabib (2006) where the international basic legal frameworks of human rights are discussed as having taken on a moral standing.

\section{Sustainability - and education - as a common good}

A discussion of ethical competence in compulsory school, contemporarily and from a social justice perspective, also needs to consider the emphasis on matters of sustainability as a social justice issue. In the UNESCO (2015) report, it is initially given crucial significance. Such an emphasis was not originally included as one of the main themes of this study; 
however, if approached at a later stage, what observations can one make regarding the five contexts on matters of sustainability as a part of ethical competence? Firstly, it can be noted that 'sustainability' or 'sustainable development' works as a search term only in the Swedish case, while for the other curricula 'environment' opens up to these matters. Regarding the Namibian curriculum for RME, it can be noted that responsibility for the environment is an integrated aspect of RME from the early school years. It grows out of a respect for nature, and forms a clear ethical responsibility to be gradually developed. The South African curricula for Life Skills and Life Orientation develop, for the first school years, ways and means to deal with environmental matters. The references thereafter are more general, regarding the environment as something surrounding the student, and care for the environment or sustainability is not emphasised. The Californian H-SSF curriculum approaches the environment from a geographical or nature geographical point of view, and care for the environment is not explicitly addressed as an ethical responsibility. In the ERC programme, environmental awareness is one of the many themes, and is also connected to consumer rights and responsibilities but not given particular weight. In its initial overall part, the Swedish curriculum emphasises an ethical responsibility for the environment, and sustainable development is addressed as an important concern. In the syllabus for knowledge of religion(s) for early school years and grades 7-9, ethical concepts linked to questions concerning sustainable development are mentioned as belonging to the core content of the subject.

\section{Discussion}

In response to the research question for this study, the results above have shown variations and offered insights into various ways of approaching matters of social justice as ethical concerns in school curricula. In dialogue with other research, the results have also been elaborated on and expanded. But some methodological questions need to be raised; for instance, to what extent are the curricula comparable? Or, are the societal contexts so divergent so as to render comparisons of the curricula, if not impossible, still what could maybe be described as 'unfair'? Does, for example, the historic approach that characterises the H-SSF curriculum from California make it complex to compare with the others, not bound by such an emphasis? Does the chosen pedagogical method there mean that when contemporary social justice issues are to be studied through interpretations of historic events, this makes contemporary issues less visible in the curriculum? Or - another matter - does the degree of concretisation that the Namibian curriculum for RME represents make it emerge more clearly than, for example, the Swedish one, which is not as detailed? Or does a more 'general values' orientation of the curricula from South Africa become a disfavour as compared to the more strongly 'ethics education' focus of the ERC programme when ethical competence is studied?

Questions like the ones above cannot be answered. That the compared curricula are different from one another could be expected, as this is how curricula operate, and the interest here is in the content variations. Methodologically speaking, being careful and nuanced in descriptions throughout the analysis and when reporting were efforts on the part of the author. Taken together, I argue that the variations shown can be of interest not only to researchers and policy-makers from these five contexts, but also to others with an interest in how to develop relevant ethical competence in relation to social justice in compulsory school education. This is valid not only from policy points of view, but also from the perspectives of classrooms, that is, in schools or teacher education.

Earlier, I argued for the choice of four of the included contexts, in contrast to the Swedish, as representing various contexts outside Europe. However, the choice of contexts also implied a conscious effort to let research in the Global North enter into dialogue with realities of the Global South, so as to contribute towards breaking up patterns of domination through existing knowledge systems and create comparisons that stretch beyond these. My estimate is that this endeavour, for example, highlighted the silencing of matters of racism, Ubuntu as an integrated ethical approach, and added emphasis on the importance of social justice aspects of sustainability matters. On the other hand, including Sweden gave the clearest expression of gender equality, which is of value as a challenge from an intersectional perspective.

I also deem it valuable to have used ethical competence as a heuristic tool in this study. This has 'freed' the curricular material from being classified into categories such as moral education, character education, moral development, religious education or others, which has served the study and opened up for the specific curricular content.

\section{Conclusion}

The present comparison of curricula from Namibia, South Africa, California (USA), Québec (Canada) and Sweden has explored how aspects of social justice are expressed in the curricula.

Demonstrating a number of variations, the study concludes that an active curricular mention of social justice aspects, such as race, class and gender, can provide more clarity as to the relevance of matters of social justice by making them more visible when directions for the forming of an ethical competence are sought.

The use of an intersectional perspective in the understanding of how patterns of power interact can, for example, come to promote gender equality - and thereby make the social justice aspects of race, class and gender an integrated part of ethical competence. In a rethinking of education (cf. UNESCO 2015) towards its becoming 'a global common good', a responsibility for sustainable development needs to become part of the ethical competence that compulsory school grants to students. Such a competence, here demonstrated as more or less integrated in the curricula, can in a participatory way be understood as integrating respect for students and their 
social situation, culture and worldview - being something of importance for education to interact with, here exemplified in the Namibian curriculum.

For policy-makers, this study can serve as a challenge to more seriously take on the task of formulating ethical competence in dialogue with contemporary social challenges, and not shy away from morally complex issues like class, gender and race.

\section{Acknowledgements Competing interests}

The author has declared that she has no financial or personal relationships which may have inappropriately influenced her in writing this article.

\section{Author's contributions}

K.S. is the sole author of this research article.

\section{Ethical considerations}

This article followed all ethical standards for a research without direct contact with human or animal subjects.

\section{Funding information}

This study is part of the research project EthiCo I funded by the Swedish Research Council 2015-2018 (Grant no. 2014-2030).

\section{Data availability statement}

Data sharing is not applicable to this article as no new data were created or analysed in this study.

\section{Disclaimer}

The views and opinions expressed in this article are those of the author and do not necessarily reflect the official policy or position of any affiliated agency of the author.

\section{References}

Ball, S.J., 2003, 'The teacher's soul and the terrors of performativity', Journal of Education Policy 18(2), 215-228. https://doi.org/10.1080/0268093022000043065

Ball, S.J., 2009, 'Privatising education, privatising education policy, privatising educational research: Network governance and the "competition state"', Journal of Education Policy 24(1), 83-99. https://doi.org/10.1080/02680930802419474

Ball, S.J. \& Olmedo, A., 2013, 'Care of the self, resistance and subjectivity under neoliberal governmentalities', Critical Studies in Education 54(1), 85-96. https:// doi.org/10.1080/17508487.2013.740678

Benhabib, S., 2006, Another cosmopolitanism, Oxford University Press, Oxford, NY.

Cannon, K.G., 1988, Black womanist ethics, Scholars' Press, Atlanta, GA.

Carbado, D.W., Crenshaw, K.W., Mays, V.M. \& Tomlinson, B., 2013, 'Intersectionality. Mapping the movements of a theory', Du Bois Review 10(2), 303-312. https://doi. org/10.1017/S1742058X13000349

Crenshaw, K.W., 1991, 'Mapping the margins', Stanford Law Review 43(6), 1241-1299. https://doi.org/10.2307/1229039

Franck, O., forthcoming, 'Critical dimensions of ethical competence in intercultural religious education: An analysis with special regard to three Nordic curricular arenas', HTS Teologiese Studies/Theological Studies 76(1), a5829.

Goodlad, J.I. \& Su, Z., 1992, 'Organization of the curriculum', in P.W. Jackson (ed.), Handbook of research on curriculum: A project of the American Educational Research Association, 327-344, Macmillan Publishing Company, New York.

Hartman, S. \& Torstenson-Ed, T., 2007, Barns tankar om livet (Children's thoughts about life), Natur och kultur, Stockholm.
Korim, V. \& Hanesová, D., 2010, 'The role of character education and its equivalent subjects in the school curriculum in Slovakia and selected countries', The New Educational Review 21(2), 81-96.

Lilja, A., Franck, O., Osbeck, C. \& Sporre, K., 2017, 'Ethical competence: A comparison between the Swedish and the Icelandic curricula and some teachers' views', Education 3-13 46(5), 506-516. https://doi.org/10.1080/03004279.2017.1284249

Lynch, I., Swartz, S. \& Isaacs, D., 2017, 'Anti-racist moral education: A review of approaches, impact and theoretical underpinnings from 2000 to 2015', Journal of Moral Education 46(2), 129-144. https://doi.org/10.1080/03057240.2016.1273825

Manni, A., 2018, 'School children envisioning future knowledge and agency within the context of education for sustainable development', in J. Ristiniemi, G. Skeie \& K. Sporre (eds.), Challenging life. Existential questions as a resource in education, $\mathrm{pp}$ 313-328, Waxmann, Münster.

McCall, L., 2005, 'The complexity of intersectionality', Signs 30(3), 1771-1880. https:// doi.org/10.1086/426800

Mulinari, D. \& Neergaard, A., 2017, 'Exploring the Swedish racial regime', Nordic Journal of Migration Research 7(2), 88-96. https://doi.org/10.1515/njmr-2017-0016

Osbeck, C., Franck, O., Lilja, A. \& Sporre, K., 2018, 'Possible competences to be aimed at in ethics education: Ethical competences highlighted in educational research journals', Journal of Beliefs \& Values 39(2), 195-208. https://doi.org/10.1080/136 journals', Journal of Be

Rest, J.R., 1986, Moral development: Advances in research and theory, Praeger, New York.

Rothgangel, M., Skeie, G. \& Jäggle, M., 2014, Religious education in Europe. Part 3 Northern Europe, Vienna University Press, Göttingen.

Silfver, E., Sjöberg, G. \& Bagger, A., 2016, 'An "appropriate" test taker: The everyday classroom during the national testing period in school year three in Sweden' Ethnography and Education 11(3), 237-252. https://doi.org/10.1080/17457823.2 015.1085323

Sporre, K., 1999, 'Först när vi får ansikten. Ett flerkulturellt samtal om feminism, etik och teologi (Only when we have faces. A crosscultural conversation on feminism, ethics and theology)', Lund studies in ethics and theology, p. 9, Atlas, Stockholm.

Sporre, K., 2015, "'Do not love anybody more than you love yourself." On ethics, oppression, and resistance', in K. Sporre (ed.), In search of human dignity. Essays in theology, ethics and education, pp. 28-37, Waxmann Verlag GmbH, Münster.

Sporre, K., forthcoming, 'Ethics education in religious and values educational frameworks: Five contexts, variations and proposals for curricular development', in D. Lankshear, L. Francis \& S. Parker (eds.), Religious and values education. Contextual challenges, Peter Lang, Bern.

Sporre, K., Franck, O., Lilja, A. \& Osbeck, C., 2020, 'Ethics education in Swedish RE and future content for ethics education in compulsory school', in I. Ter Avest, C. Bakker, P. Schreiner, J. Ipgrave \& S. Leonhard (eds.), Facing the unknown future. Religion and education on the move, pp. 195-208, Waxmann, Münster.

Swartz, S., 2011, 'Being turned inside out: Researching youth, morality and restitution from the Global South', Journal of Moral Education 40(3), 407-415. https://doi.or $\mathrm{g} / 10.1080 / 03057240.2011 .596344$

United Nations Educational, Scientific and Cultural Organization (UNESCO), 2015 Rethinking education. Towards a global common good?, United Nations Educational, Scientific and Cultural Organization, Paris.

Vaismoradi, M., Turunen, H. \& Bondas, T., 2013, 'Content analysis and thematic analysis: Implications for conducting a qualitative descriptive study', Nursing and Health Sciences 15(3), 398-405. https://doi.org/10.1111/nhs.12048

Van der Walt, J.L., 2019, 'The search for a moral compass and a new social contract in the context of citizenship education', HTS Teologiese Studies/Theological Studies 75(4), a5359. https://doi.org/5310.4102/hts.v5375i5354.5359

Young, I.M., 1990, Justice and the politics of difference, Princeton University Press, Princeton, NJ.

Young, I.M., 2000, Inclusion and democracy, Oxford University Press, Oxford.

Ziebertz, H.-G., 2016, 'Human dignity - the foundation of political human rights? Empirical research among youth in Germany', Journal of Beliefs \& Values 37(2), 151-171.

\section{Curricula studied}

\section{Namibia}

IRC, 2014, Implementation of the revised curriculum for basic education, 2014 viewed 06 May 2016, from https://www.moe.gov.na/files/downloads/bd7 Information $\% 20$ on $\% 2$ Revised $\% 20$ Curriculum $\% 20 \% 20$ Ministry $\% 20$ of $\% 20$ Education $\% 202014 \% 20$ updated $\% 20$ on $\% 2029$ th $\% 20$ August $\% 202014 \% 20(1)$.pdf.

RME, 1-4, Religious and Moral Education, 2005, Lower primary phase syllabus, pp. 129-147, Ministry of Education, National Institute for Educational Development (NIED), Okahandja.

RME, 5-7, Religious and Moral Education Syllabus, 2007, Upper primary phase, Ministry of Education, National Institute for Educational Development (NIED), Okahandja.

RME, 8-10, Religious and Moral Education Syllabus, 2007, Junior secondary phase, Ministry of Education, Okahandja, viewed 06 April 2016, from https://www.moe. gov.na/st_syllabi.php2016-04.

\section{South Africa}

Life Skills, R-3, 2011, English life skills. Foundation phase Grades R-3, Department Basic Education viewed 18 April 2016, from https://www.education.gov.za/Curriculum/ CurriculumAssessmentPolicyStatements(CAPS)/CAPSFoundation.aspx. 
Life Skills, 4-6, 2011, Life skills. Intermediate phase, Department Basic Education, viewed 18 April 2016, from https://www.education gov.za/Curriculum/Curriculu mAssessmentPolicyStatements(CAPS)/CAPSIntermediate.aspx.

Life Orientation, 7-9, 2011, Life orientation. Senior phase, Grades 7-9, Department Basic Education, viewed 18 April 2016, from https://www.education.gov.za/ Curriculum/CurriculumAssessmentPolicyStatements(CAPS)/CAPSFET.aspx.

Life Orientation, 10-12, 2011, Life orientation, further education and training phase Grades 10-12, Department Basic Education, viewed 18 April 2016, from https:// www.education.gov.za/Curriculum/CurriculumAssessmentPolicyStatements (CAPS)/CAPSFET.aspx.

Religion Studies, 10-12, 2011, Religion studies. Further education and training phase Grades 10-12, Department Basic Education, viewed 18 April 2016, from https:// www.education.gov.za/Curriculum/CurriculumAssessmentPolicyStatements (CAPS)/CAPSFET.aspx.

\section{California State, USA}

H-SSF, 2005, History-social science framework for California Public Schools, Kindergarten through Grade Twelve, California Department of Education, viewed 15 May 2015, from https://www.cde.ca.gov/ci/cr/cf/documents/histsocsciframe.pdf.

\section{Sweden}

Lgr11, 2011, Läroplan för grundskolan, förskoleklassen och fritidshemmet 2011 viewed 08 April 2015, from https://www.skolverket.se/laroplaner-amnen-ochkurser/grundskoleutbildning/grundskola/laroplan.

Lgr11 (English version), 2011, Curriculum for the compulsory school, preschool class and the recreation centre 2011, viewed 08 April 2015, from https://www. skolverket.se/laroplaner-amnen-och-kurser/grundskoleutbildning/grundskola/ engelska.

\section{The Province of Québec, Canada}

ERC-EE, 2008, Ethics and religious culture program, elementary education, Quebec Education Program, viewed 27 April 2016, from https://www.education.gouv.qc.ca/ fileadmin/site_web/documents/dpse/formation_jeunes/ecr_elementary.pdf.

ERC-SE, 2008, Ethics and religious culture program, elementary education, Quebec Education Program, viewed 28 April 2016, from https://www.education.gouv. qc.ca/fileadmin/site_web/documents/dpse/formation_jeunes/ecr_secondary.pdf. Just landed, Canada Guide, Public Schools, viewed 28 April 2016, from https://www. justlanded.com/english/Canada/Canada-Guide/Education/Public-Schools. 